\title{
CORPORATE SOCIAL RESPONSIBILITY IN FOODSERVICE BUSINESS IN POLAND ON SELECTED EXAMPLE
}

\section{EDYTA GHERIBI}

University of Lodz, POLAND

e-mail: edyta.gheribi@uni.lodz.pl

RECEIVED
ACCEPTED
JEL
CLASSIFICATION

KEYWORDS

ABSTRACT
7 April 2017

1 September 2017

L83, M14, M21, M48

CSR, gastronomy, business, management, strategy

Corporate social responsibility (CSR) is the company's strategy, based on the assumption that business is responsible for the society within which it operates. The concept evolved strongly since its first presentation in 1953. CSR is becoming an important issue in the gastronomy business. The main objective of the article is its presentation of the concept from international and Polish perspectives, including own research aiming at the evaluation of CSR implementation. McDonald's is a good example for implementation of the CSR strategy and for that reason it was chosen for in-depth analysis in the article.

\section{Introduction - Historical background of CSR}

The CSR concept was proposed in 1950s, and it keeps evolving. CSR was defined in 1953 by Bowen as "the obligations of businessmen to pursue those policies, to make those decisions, or to follow those lines of action which are desirable in terms of the objectives and values of our society" (Bowen, 1953). 
This point was stressed by Davis who in 1960 described business social responsibilities as "the businessman's decisions and actions taken for reasons at least partially beyond the firm's direct economic or technical interest... which need to be commensurate with the company's social power" (Davis, 1960).

During 1960-1970, the proliferation of CSR definitions is mainly due to the increasing awareness of stakeholder (e.g. labors and consumers) own rights and government regulations.

The earliest reference addressing specifically social auditing was around early 1960 in a book by Goyder (1961).

However, the development of CSR definitions during 1980 became more specific and extended to various themes, for instance, corporate social responsiveness, corporate social performance and stakeholder theories. One of the most notable experimental studies was conducted by Corchran and Wood (1984). They examined the impacts of social responsibility on corporation financial performance using reputation index as an indicator. Aupperle, Carroll and Hatfield (1985) first applied a theoretical definition of CSR proposed by Carroll (1983) into CSR assessment indicators, which involves four components: economic, legal, ethical and discretionary.

In 2000 globalisation, acting as the worldwide penetration of market-driven corporate enterprise, stimulated the development of CSR, which focuses on responsibility of citizenship without borders (Vogel, 2005; Crane, McWiliams, Matten, Moon, Siegel, 2008).

The European Commission has defined CSR as the responsibility of enterprises for their impact on society (European Commission, 2017). The European Commission believes that CSR is important for the sustainability, competitiveness, and innovation of EU enterprises and the EU economy. It brings benefits for risk management, cost savings, access to capital, customer relationships, and human resource management. Companies can become socially responsible by (European Commission, 2017): following the law; integrating social, environmental, ethical, consumer and human rights concerns into their business strategy and operations.

In addition to the divergence in definitions, companies from different industries also have specific strategies and concerns of CSR implementation (Belu, Manescu, 2013). Despite this, different criteria from the different types of companies still focus on three main concepts, involving environmental, social and economy which is consistent with three bottom lines (Elkington, 1994; Crane et al., 2008; Belu, Manescu, 2013).

CSR in this work is generally understood as being the way through which a company achieves a balance of economic, environmental and social imperatives ("Triple-Bottom-Line- Approach"), while at the same time addressing the expectations of shareholders and stakeholders.

The aim of this paper is to evaluate the current performance of CSR in Polish gastronomic business in terms of its contribution to the well-being of the environment, community and economy.

\section{Method}

Reviewing of current CSR implementation in Poland in gastronomy businesses was illustrated by the empirical method, qualitative research method - case study. Case studies show detailed contextual analysis of declarations of the CSR of McDonald's. McDonald's was chosen as a subject matter of the study mainly because of its universal appeal and its marked dedication to CSR initiatives. Before McDonald's was selected for the analysis, other companies were observed in their behaviour on CSR. Positive behavior has been found in international operators such as KFC, Starbucks and the Polish company Sfinks Polska SA. However, the greatest CSR activity was noticed in McDonald's, so it was decided to put across details of their activities in this area. 


\section{Results}

The development of the CSR concept in Poland is still at an early stage. Studies carried out in Poland and other European Union countries prove that large businesses are often engaged in social reporting. Polish enterprises, and in particular MSME, still do not fully appreciatiethe importance of CSR. They focus mainly on achieving shortterm market goals without a long-term strategic vision. Small and medium-sized enterprises are reluctant to engage in the preparation and publication of social reports. According to the CorporateRegister.com site, only $4 \%$ of all CSR-reporting businesses are SMEs. Note that SMEs account for about $98 \%$ of all businesses.

Based on the conducted analyses, the status of the development of the CSR concept in Poland in 2014 was assessed. The ratings obtained by Poland in the four analysed areas allow a conclusion to be made that in 2014 Poland became closer to the $\mathrm{C}$ level - attentive and emerging - in the development of the CSR concept. This rating comprised: (Wołczek, 2015, pp. 211-212)

- The area of legal and political environment: there is a new (established in July 2014) named government department leading on CSR issues but there is no CSR national strategy.

- The area of civil society context: there are universities and research institutes offering specific programmes and courses in CSR and related fields. There is still no widespread civil society involvement in the structured and publicly disclosed dialogue with companies openly aiming at developing a corporate strategy.

- The area of reporting: only 12 out of the 100 largest Polish companies have published a CSR report in 2010. The number of regularly produced, structured CSR reports is increasing from year to year but is still low and independent assurance is at a preliminary stage. There is no widespread adoption of formal public disclosure of CSR issues and data by small and medium-sized enterprises.

- In the area of standards: in 2012 there were more than two thousand companies in Poland, which were independently certified to ISO 14001.

Companies providing gastronomy services did not appear in the top 10 of the Responsible Business Ranking 2016 (Responsible Business Forum in Poland, 2016). However, regardless of the current absence in the rankings, the companies operating in the Polish gastronomy industry increasingly rely on the implementation of the principles of social responsibility, seeing in it an effective business strategy and a source of competitive advantage. The interest in CSR in gastronomy businesses increases alongside the growing standard of living, increasing the role of eating out habits and the increasing awareness of Poles as both consumers and citizens.

As the general public and government have better awareness of the significance of healthier diet and food safety, the requirements for food industry are not merely the quality of food and service, but also the hygiene conditions of their personnel and facilities (Drosinos, Gialitaki, Paramithiotis, Metaxopoulos, 2005). Experimental researches indicate that a large portion of consumers prefer to have accessible information on menus or prepacked food, such as nutrition composition and ingredients (Hoefkens, Veettil, Van Huylenbroeck, Van Camp, Verbeke, 2012; Fifka, Loza Adaui, 2015).

We can observe a global trend to implement CSR in the gastronomy business, especially in multinational fastfood chain restaurants, such as McDonald's, KFC, Burger King and Starbucks.

The majority of companies operating in the Polish gastronomy industry are micro companies that employ up to 9 employees (96\%). Only $3.7 \%$ are small companies and $0.13 \%$ are medium companies. Large companies in the gastronomy industry make up only $0.02 \%$ (GUS, 2016). $2 / 3$ companies whose representatives declare awareness of the term "corporate social responsibility" conduct activities related to it. In the group of companies from the whole 
of Poland, these are much less often micro enterprises (56\% mentions) compared to other companies (approx. $80 \%$ mentions) (PARP, 2011).

\section{Case study - McDonald}

The CSR concept can have varying levels of importance for different organisations. In order to understand the extent to which modern organisations have adapted CSR into their everyday business objectives, a case study of the popular fast food chain McDonald's was attempted. McDonald's was chosen as a subject matter of the study mainly because of its universal appeal and its marked dedication to CSR initiatives. McDonalds' CSR strategy is lucid and well etched out. Thus, it would be easy to apply the understanding from the study to companies across functions and industries.

McDonald is the world's leading global food service chain with more than 35,000 locations serving approximately 70 million customers in more than 100 countries each day. More than $80 \%$ of McDonald's restaurants worldwide are owned and operated by independent local businessman. McDonald's in Poland has 384 restaurants in more than 150 cities, over 19,000 workers, close to half a million guests every day.

Companies often choose to align their brand image and objectives with their CSR objectives. This is adequately illustrated in the case of McDonalds.

At the cornerstone of their CSR initiatives is the set of 'values' outlined by the company. McDonald's CSR report (2016) contains an explicit commitment and mission to make progress, including the operation of an ethical and sustainable manner as well as concerns about their influences on environment and society.

McDonald's mission is to consistently provide every customer with the best possible restaurant experience. To fulfill this mission, they are committed to being a socially responsible company, as an active member of the community. It is their duty to listen to the opinions of stakeholders including their customers and those of local communities and to take appropriate actions in good faith in response. Therefore, they engage in corporate social responsibility activities (Table 1 ).

Quality control is the top priority to ensure product safety for customers. To achieve this, they work with all their suppliers in close partnerships, setting strict standards for the sourcing of raw materials and quality control in every step across their value chain from farms to processing plants, distribution channels, and to their restaurants. McDonald's has been making huge changes to its menu over the past years. Therefore the company uses only products and raw materials that must meet the strictest safety and quality criteria and not least they must be tested and approved by all relevant institutions. McDonald's has developed its SQMS, a quality management system for food suppliers. The McDonald's standard focuses largely on the requirements that vendors should meet and addresses such issues as product design principles, management responsibility requirements, crisis management requirements, and verification requirements, and continuous system improvement (Gazeta Praca, 2015). An important role in ensuring food security is provided by systems, which relate to the quality of production. Among them are universal quality systems, which include, among others ISO, TQM, and food quality systems. This type of system is divided into systems addressed to processing and marketing (HACCP, GMP, GHP, BRC, IFS). One of the systems that regulate the production of safe food is the HACCP system. In Poland in 2014, only 39\% of gastronomy companies had implemented HACCP and $94 \%$ were prepared to implement the system (Stępniak, 2015). The control conducted by Office of Competition and Consumer Protection indicates various types of misconduct were found in $79.5 \%$ of inspected gastronomy enterprises, were mainly (UOKiK, 2011): offering foods or drinks of 
the wrong quality (21.4\%), offering overdue goods (18.4\%), failure to observe storage conditions (14.4\%), lack of medical certificates for sanitary and epidemiological purposes of employees which have contact with food (8.0\%).

Table 1. CSR in McDonald's

\begin{tabular}{|c|c|c|c|}
\hline Stakeholder group & Activities & Key areas & How do they address the issues \\
\hline Customers/Consumers & $\begin{array}{l}\text { Surveys } \\
\text { Research }\end{array}$ & $\begin{array}{l}\text { Carbon footprint } \\
\text { Human rights compliance } \\
\text { Fiber sourcing } \\
\text { Impact of products on people } \\
\text { and nature }\end{array}$ & $\begin{array}{l}\text { Life Cycle Assessments } \\
\mathrm{CO}_{2} \text { target } \\
\text { Sourcing target } \\
\text { Business Practice Reviews } \\
\text { Eco actions } \\
\text { Product safety } \\
\text { Chemicals }\end{array}$ \\
\hline Employees & $\begin{array}{l}\text { Training } \\
\text { Feedback }\end{array}$ & $\begin{array}{l}\text { Talent management } \\
\text { Performance management } \\
\text { Workforce planning } \\
\text { Compensation and benefits } \\
\text { Corruption } \\
\text { Health and Safety }\end{array}$ & $\begin{array}{l}\text { Code of Conduct training } \\
\text { OHSAS } 18001 \text { certification } \\
\text { All employees survey } \\
\text { Diversity survey } \\
\text { Global Performance Management System }\end{array}$ \\
\hline Investors & $\begin{array}{l}\text { SRI questionnaires } \\
\text { One-on-one meetings } \\
\text { Telebriefings } \\
\text { Analyst interviews } \\
\text { Roadshows } \\
\text { Field visit }\end{array}$ & $\begin{array}{l}\text { ESG integration into business } \\
\text { strategy } \\
\text { Energy efficiency } \\
\text { Risk management }\end{array}$ & $\begin{array}{l}\text { Inclusion in sustainability funds and indexes } \\
\mathrm{CO}_{2} \text { target } \\
\text { ESAVE } \\
\text { Code of Conduct audits and Business Practice } \\
\text { Reviews } \\
\text { Risk analysis }\end{array}$ \\
\hline Suppliers & $\begin{array}{l}\text { Supplier audit } \\
\text { Supplier questionnaires }\end{array}$ & Raw material sourcing & $\begin{array}{l}\text { Sourcing target } \\
\text { Supplier guidelines and standards } \\
\text { Supply chain assurance }\end{array}$ \\
\hline Society & $\begin{array}{l}\text { Participation in industry initiatives } \\
\quad \text { and standardization bodies } \\
\text { Ongoing dialog } \\
\text { Community involvement }\end{array}$ & $\begin{array}{l}\text { SCA's dialog with society } \\
\text { Community involvement }\end{array}$ & $\begin{array}{l}\text { Public affairs } \\
\text { Stakeholder dialog } \\
\text { Membership in organizations } \\
\text { Community relations initiatives }\end{array}$ \\
\hline
\end{tabular}

Source: own study based on CSR McDonald's information (http://mcdonalds.pl/omcdonalds/odpowiedzialnosc; http://corporate.mcdonalds. com/mcd/sustainability/sustainability_CR_reports.htm).

McDonald's company requires that its suppliers use mainly natural and no genetically modified ingredients. McDonalds is operating in a society with a high focus on health and obesity, the company has, thus, over the past years, incorporated healthier options into its menus alongside nutritional information and education to reflect the public concerns for obesity and other health issues such as heart diseases and diabetes, which are inevitably connected to its products. Like many fast food chains, McDonald's are starting to offer healthy choices on their menus to attract more health conscious consumers. The chain added to its' menu salads, yogurts, vegetables, fruits, mineral water and juices. The Company is committed to helping customers make informed nutrition choices. From printed brochures and nutrition labeling right on select food packaging, to innovative mobile apps, QR codes and online nutrition calculators, as well as calories on menu boards, multifaceted approaches give McDonald's customers the information they seek in many markets around the world.

The company puts great emphasis on employees - of the possibility of personal growth and development. The company is also based on several values and principles such as respect, open communication and equally substantial and professional development support. An important factor is the fact that McDonald's is able to provide 
work for such groups of workers who face many difficulties finding a job, such as young people without work experience, women with children or handicapped persons.

In companies operating in Poland, only $14 \%$ have written procedures on how to counteract discrimination in the workplace and during the recruitment process (PARP, 2011). In general, companies do not provide facilitations to disadvantaged groups for finding a friendly workplace. Another area of CSR is "labour practices". How employees are treated - instrumentally (they are the company's capital, used only for maximizing profits) or as actors (employees as partners in action) - this aspect differentiates companies with respect to responsible businesses. One of the indicators of responsible business in relation to employees is the opinion on the employee turnover rate. Struggling retail and catering industries have the greatest employee turnover rate. Gastronomy has also been at the forefront of the sectors with the highest employment in the informal sector. The number of workers "on the black" grows sharply in summer. A survey conducted by Sedlak \& Sedlak among restaurant employees in one of Poland's provincial cities shows that almost $35 \%$ employees in the catering industry work illegally. Most of them are seasonal workers (T.B., 2011). The employee turnover rate in accommodation and catering in 2015 was higher than 30\% (GUS, 2016). As many as $66 \%$ of entrepreneurs from Poland indicated that the timely payment of wages it is actually over-standard action, aimed at increasing employee satisfaction. According to Labor Law, this should be standard procedure, not a special distinction (PARP, 2011). But in the catering industry this situation happens very often.

With regard to environmental responsibilities and with a viewpoint of continuous optimisation, McDonald's Poland is implementing a nationwide programme to reduce $\mathrm{CO}_{2}$ emissions in all restaurants. The project partners are the key suppliers of McDonald's. In comparison to the base year (2012) the achieved emission reduction was $27 \%$. McDonald's in 2015 was using certified renewable energy (green energy) in restaurants throughout the country. McDonald's introduced mixed transport (rail) in the logistics of their products and implemented a programme to reduce water consumption at McDonald's. More than a decade ago, McDonald's Poland was the first company in Poland to receive the Environmental Management System Certificate in accordance with ISO 14001: 2004. Subsequent periodic audits confirmed that environmental protection is a company priority. Recycling plays an increasingly important role in the management of waste. McDonald's Poland leads in their restaurants throughout the country with segregation of waste from the kitchen and dining room. The company also runs a national project for full development and re-use of frying oil. It is entirely received and processed at the refinery for biodiesel. All packaging in McDonald's are produced on the basis of paper and cardboard.

As few as one in ten companies from the Polish sample inform the local community about the pollution generated by the company. Out of the companies that inform the local community about the pollution generated as a result of its activity, less than half also consult the community about how to limit this impact (PARP, 2011).

The CSR of McDonald's in relation to the community was also analysed. McDonald's is involved in charitable activities and supports the needy, especially children. Ronald McDonald's foundation is a charity of which the core activity is creating Houses for parents of children struggling with serious diseases who watch over their kids. The charity has already established 345 houses around the world. On 14th October 2015, the charity opened its first House in Poland at University Children's Hospital of Kraków Prokocim, thanks to support and partnership of Jagiellonian University Medical College. More information about the foundation's activities can be found at www. frm.org.pl.

Philanthropy or charity, this area is undervalued and not perceived by entrepreneurs as a type of activity that brings benefits to the community as well as the company by projecting a positive image of the company in 
the community, having a competitive edge or contributing to solving specific community problems. Every fourth company from Poland undertakes some action to the benefit of the local community (PARP, 2011).

The company is reporting continued progress around the world in its social responsibility efforts. In an update that details global advances, highlights include environmental and sustainability initiatives, non-governmental organisation partnerships, animal welfare audits, support of children's causes and healthy lifestyle activities.

\section{Resullts supply}

The main supply for the article was McDonald's case study and secondary resources. To deepen the analysis, professional and theoretical data were included.

\section{Results demand}

The demand for results is related to a poor adoption of CSR in small companies, especially in the gastronomy business. There is a possibility to improve performance with the example of McDonald's as the role model.

\section{Limitations}

The main limitation for implementation of the results and interpretation is related to the case study method itself. It gives no guarantee that the implemented strategies will result in spectacular results, especially due to the activities undertaken in parallel to CSR, i.e. branding. Still, this can be a starting point for the CSR strategy implementation in gastronomy business in other companies.

\section{Conclusions}

CSR is a compelling strategy for sustainable business, which was primarily implemented in developed countries. The definition of the concept evolved from 1953 and was enriched by various aspects and contexts. The development of the CSR concept in Poland is still at an early stage. Some of the areas are developing slightly more dynamically than others and some are characterised by stagnation. Polish enterprises, and in particular MSME, still do not fully appreciate the importance of CSR.

There is a huge potential of CSR implementation in the gastronomy business, for which McDonald's is a good point of referral. The example can be transferred not only to similar fast food restaurants, but generally speaking to most of the companies.

As we can see there are many benefits that CSR can offer to organisations. But the problem still remains detection, quantification and assessment of these benefits.

\section{References}

Aupperle, K.E., Carroll, A.B., Hatfield, J.D. (1985). An empirical examination of the relationship between Corporate Social Responsibility and profitability. Academy of Management Journal, 2 (28), 446-463.

Belu, C., Manescu, C. (2013). Strategic corporate social responsibility and economic performance. Applied Economics, 19 (45), 2751-2764.

Bowen, H. (1953). Social Responsibilities of the Businessman. New York: Harper and Row Press.

Carroll, A.B. (1983). Corporate social responsibility: Will industry respond to cutbacks in social program funding? Vital Speeches of the Day, 49, 604-608. 
Cochran, P.L., Wood, R.A. (1984). Corporate Social Responsibility and Financial Performance. Academy of Management Journal, 1 (27), 42-56.

Crane, A., Matten, D. (2007). Business Ethics, 2nd edn. Oxford: Oxford University Press.

Crane, A., McWiliams, A., Matten, D., Moon, J., Siegel, D. (2008). The Oxford Handbook of Corporate Social Responsibility. OUP Oxford Press.

Davis, K. (1960). "Can Business Afford to Ignore Social Responsibilities?" California Management Review, 2/3, 70-76.

Drosinos, E., Gialitaki, M., Paramithiotis, S., Metaxopoulos, J. (2005). A survey of the microbiological quality of some food catering services in Greece. Italian Journal of Food Science, 4 (17), 469-476.

Elkington, J. (1994). Towards the Sustainable Corporation: Win-Win-Win Business Strategies for Sustainable Development. California Management Review, 2 (36), 90-100.

European Commission (2017). Retrieved from: http://ec.europa.eu/growth/industry/corporate-social-responsibility_pl (11.01.2017).

Fifka, M., Loza Adaui, C.R. (2015). "CSR Reporting - Administrative Burden or Competitive Advantage”. In: L. O'Riordan, P. Zmuda, S. Heinemann (eds.), New Perspectives on Corporate Social Responsibility: Locating the Missing Link (pp. 285-300). Springer Gabler, Germany.

Gazeta Praca (2015). Retrieved from: http://www.gazetapraca.biz/czy-wiesz-ze-mcdonalds-ma-swoja-norma-jakosciowa-sqms.

Goyder, G. (1961). The responsible company. Oxford: Blackwell Press.

GUS (2016). Statistical Yearbook. Warszawa: GUS.

Hoefkens, C., Veettil, P., Van Huylenbroeck, G., Van Camp, J., Verbeke, W. (2012). What nutrition label to use in a catering environment? A discrete choice experiment. Food Policy, 6 (37), 741-750.

http://corporate.mcdonalds.com/mcd/sustainability/sustainability_CR_reports.html.

https://ddd.uab.cat/pub/infsos/47133/isMCDONALDSa2015ieng.pdf.

http://www.mcdonalds.co.jp/company/csr/pdf/CSR2016_e.pdf.

http://mcdonalds.pl/o-mcdonalds/odpowiedzialnosc.

https://badania.parp.gov.pl/files/74/75/77/13079.pdf.

PARP (2011). Ocena stanu wdrazania standardow spolecznej odpowiedzialnosci biznesu. PARP report MillwardBrown SMG/KRC. Warszawa: PARP.

Raport. Odpowiedzialny biznes (2015, 2016). Warszawa: Forum Odpowiedzialnego Biznesu.

Responsible Business Forum in Poland (2016). Retrieved from: http://odpowiedzialnybiznes.pl/aktualno\%C5\%9Bci/wyniki-rankinguodpowiedzialnych-firm-2016 (19.05.2016).

Stępniak, K. (2015). Mocno w górę, Raport 2015 rynek gastronomiczny w Polsce. Warszawa: BROG.

T.B. (2011). Co trzeci pracownik gastronomii w szarej strefie. Gazeta Prawna.pl. Retrieved from: http://praca.gazetaprawna.pl/ artykuly/483642,co-trzeci-pracownik-gastronomii-w-szarej-strefie.html (2.02.2011).

UOKiK (2011). Report. Konsument na rynku uslug gastronomicznych w swietle kontroli przeprowadzonych przez Inspekcje Handlowa w roku 2010. Warszawa: UOKiK.

Vogel, D. (2005). The Market for Virtue: The Potential and Limits of Corporate Social Responsibility. Brookings Institution Press.

Williamson, N., Stampe-Knippel, A., Weber, T. (2014). Corporate Social Responsibility National Public Policies in the European Union Compendium.

Wołczek, P. (2015). Development of the Csr Concept in Poland - Progress or Stagnation? Research Papers of Wrocław University of Economics, 387, 200-214.

Cite this anticle aS: Gheribi, E. (2017). Corporate social responsibility in gastronomy business in Poland on selected example. European Journal of Service Management, 3 (23), 13-20. DOI: 10.18276/ejsm.2017.23-02. 